Ann. Génét. Sél. anim., I979, 11 (3), 27 I-280.

\title{
Review
}

\section{A review of literature on the syndrome of arthrogryposis and palatoschisis (S.A.P.) in Charolais cattle 1976-1979 (1)}

\section{J. J. LAUVERGNE, W. E. HOWELL*, F. RIEGER** and A. FAUCON***}

\author{
Département de Génétique animale, \\ Centre national de Recherches zootechniques, I.N.R.A., \\ 78350 Jouy-en-Josas, France \\ *Department of Animal Science, University of Saskatchewan, Saskatoon, Saskatchewan, \\ Canada, S7NOWO \\ **I.N.S.E.R.M., UI53, Groupe de Recherches Biologie \\ et Pathologie neuro-musculaives : Physiologie des myopathies, \\ I7, rue du Fer-à-Moulin, 75005 Paris \\ ***Institut technique de l'Élevage bovin, \\ I 49, rue de Bercy, 75579 Paris Cedex I2
}

\section{Summary}

Twenty or so papers concerning S.A.P. have been published since 1976 and can be added to the 49 already included in a descriptive bibliography published in 1976 .

Important information on the syndrome has been added: the age of the embryo at first appearance has been determined (about 3.5 months). An identifiable anomaly affects the nervous system at the level of the motor end plaque, followed by a disorganisation of muscle tissue. The anomaly presents similarities with a hereditary condition in the mouse known as muscular dysgenesis (mdg).

The frequency of the syndrome in purebred Charolais in France as well as in Canada has been reported at $0.5 \mathrm{p}$. I oo among newborn calves. The gene frequency is $q=0.20$ and penetrance in homozygotes is 0.15 and 0.08 in males and females respectively.

It has been demonstrated that penetrance may appear to be complete as a result of differences in the probabilities of affected calves being reported depending on the numbers occuring in individual herds or sire groups. It is also pointed out that breeding experiments using animals already identified as carriers could result in elevated estimates of penetrance.

Two methods of detecting carrier bulls have been applied: using a test herd of carrier females as in Canada or in the normal course of progeny performance testing pure bred beef cattle as in France. In each case only a small number of bulls can be tested compared with the number required to meet the needs of the breed.

Total eradication of calf losses by S.A.P. is not only theoretically impossible but could even be undesirable, at least from an economic point of view since heterozygous females may be sufficiently more prolific to more that compensate for the low losses resulting from the presence of the gene in the population. Nevertheless, national associations of Charolais breeders have other concerns than those associated with the genetics of calf losses, namely commercial considerations.

(1) Presented at a conference of the International Charolais Federation (F.I.A.E.R. B.C.) Vichy, France, September 7, 1979 . 
To conclude, it would be desirable to continue monitoring the occurence of S.A.P. calves to avoid confusion with other abnormalities. Continued studies of manifestations of the gene at all levels (histological, histochemical, etc.) and on the etiology of the anomaly are also recommended. Finally, additional investigations of the possible advantage in prolificacy of heterozygous females should be undertaken.

\section{Contents}

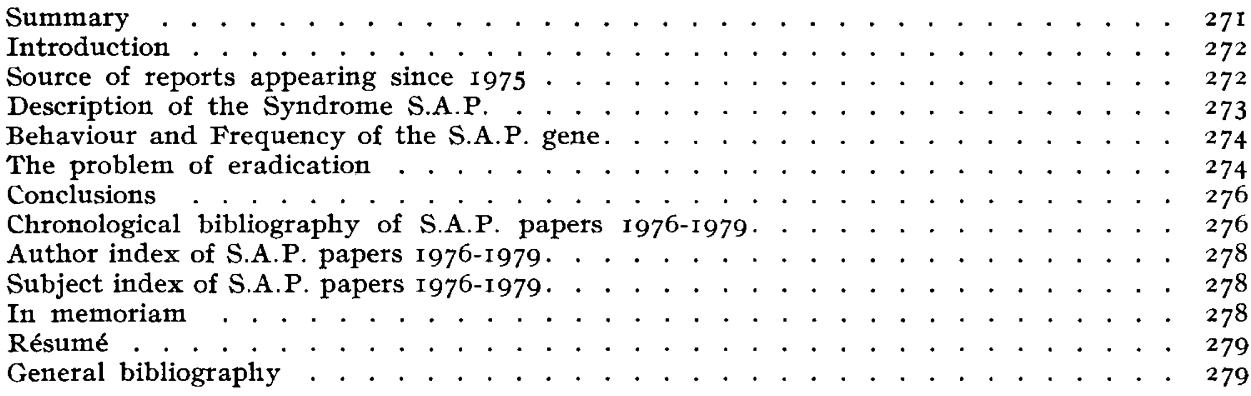

\section{Introduction}

The first scientific publications of the Arthrogryposis and Cleft Palate Syndrome (S.A.P.) appeared in I967 (LAUVERGNE et BIIN).

A bibliography prepared by LAUVERGNE and FAUCON (I976) contained 49 papers published during the period I $967-75$. Since then some 20 additional articles have been published on this subject which are reviewed in this paper.

\section{Source of the Reports Appearing Since $\mathrm{I} 975$}

There is a series of articles describing the investigations conducted at the University of Saskatchewan, Saskatoon, Canada supported financially by the Canadian Charolais Association (C.C.A.) and the International Charolais Federation (F.I.A.E.R.B.C.): QuANTz (1976), Russei, (1976a), Russel (1976b), Anonymous (1977), Nielsen et al. (I977), Russei (I977), Anonymous (I 978), Russel (1979).

There have been reports from Edmonton, Alberta (GoONEwARDENE and BORG, I976) and from Saskatoon (HOWELL and LAUVERGNE, I978) the latter dealing with a survey of Charolais breeders in Saskatchewan.

In France, I,EFORT et al. (I977) have analyzed the results from a series of ro tests of Charolais bull-calves, while RIEGER (I979) has presented the first results of a French neurobiological study of the neuromuscular system of S.A.P. calves.

Reports from Great Britain (LOGUE et al., r977, JACksON, I978), Belgium (HANSET et al., I978) and Australia (HARTLEY and WANNER, I974, overlooked in the listing by LAUVERGNE and FAUCON, I976) have recorded cases of S.A.P. appearing in Charolais in these countries. 
Included also is a report on the Canadian situation requested by F.I.A.E.R.B.C. (LAUVERGNE, I976), on the prospects of eradication (LAUVERGNE and HOWELL, I977) and on the situation in the United States of America ( $\mathrm{LAU}_{\mathrm{A}}$ VERGNE, 1979).

\section{Description of the syndrome (S.A.P.)}

These last years have seen marked progress in an understanding of the histopathology of S.A.P. beginning in I 976 with work by RUSSEL, on which he reported at the Monterrey Convention (RUSSEL, I977) and described in detail in his Ph. D. thesis of 1979 .

Using a part of the C.C.A.'s experimental herd assembled at Goodale near Saskatoon, RUSSEL obtained embryos displaying various stages in the development of the syndrome. In addition he studied S.A.P. calves at birth.

From this study if was possible to determine the prenatal age of the embryo at which the syndrome could first be detected ( 3.5 months) and the kind of abnormalities present at this age: retraction of axons from the post-synaptic membranes.

It appears that a change in the differentiation of neurons could be the cause of muscle hypotonia and the accompanying leg deformities observed in S.A.P. calves.

In the muscle of newborn S.A.P. calves, structural abnormalities are evident at the level of the neural plaques accompanied by faulty differentiation of missle fibers.

The characteristics of nerve-striated muscle interaction in the S.A.P. calf have been specified by RIEGER (I979) and RIEGER et al. (r980). A detailed parallel study in a neuromuscular mutant in the Mouse ("Muscular dysgenesis" $m d g$ ) has shown similarities in the morphological expression of the neuropathologic impairment: the atrophic muscular fibers present a disorganized myofibrilar structure ( $Z$ stria), the innervation networks are deeply desorganized as shown by tests of metallic impregnation of nerves, with a lot of contacts with an immature aspect and an abnormal distribution of the innervation (RIEGER and PINçONRAYMOND, I980).

There are also defects of biochemical nature: in the Mouse the biosynthesis of molecular forms of acetylcholinesterase is quite incomplete (as NA.WROT, r976; NAwro' et al., r979 have also pointed out). In the S.A.P. calf the mechanisms of localisation and restriction of the specific molecular forms of innervation are abnormal. The functional receptor of acetylcholine (neurotransmitter of the neuromuscular synapse) shows an aberrant distribution in the $m d g$ mouse as well as in the S.A.P. calf.

The irregular character of the affected muscles has been stressed by RIEGER (I979). The choice of abnormals examined by RusselL (r979) (all cases has a cleft palate) must not detract from the fact that there are frequent cases where the animal has analogous muscular and tendinous abnormalities but lacks the cleft palate and can be classed as true S.A.P. (LEIPOLD et al., I969, GIRoud, I975, LAUVERGNE, I975). 


\section{Behaviour and frequency of the S.A.P. gene}

Studies already cited by LAUVERGNE and FAUCON (I976) such as that of LAUVERGNE (I975), established that the S.A.P. condition was hereditary, monofactorial, and caused by an autosomal recessive gene. Although in France the gene seems to have incomplete penetrance, it may be complete in certain cases, at least in Canada.

In France this result has been confirmed beyond doubt from an analysis of beef cattle test data obtained from purebred animals (LEFORT et al., I977); estimations of penetrance were 0.15 for males and 0.09 for females and the gene frequency was calculated to be 0.20 .

Similar frequencies of the abnormality were revealed by a survey among Charolais breeders in Saskatchewan (HOWELL and LAUVERGNE), r978) after allowance was made for percentage of Charolais breeding in the crossbreds. This would indicate that the penetrance of the gene is not influenced significantly by crossing with other breeds.

The first explanation of the almost total penetrance estimated from data obtained from cattle breeders such as reported by NAwrot (r973) in Canada or HANSET et al. (I978) in Belgium derives from the fact that inclusion of the proband (the first observation) strongly biassed the date because of its variable probability of observation: escaping inclusion when only one abnormal appears but certain to be included when several abnormal calves appear in a short time span within a herd.

This explanation could nevertheless hardly be applied to account for the mendelian segregation compatible with complete penetrance of the recessive homozyzote observed in the experimental crosses conducted at Kinsella (BERG and Goonevardene, I974) or at Goodale (NIELSEN et al., I976).

Two comments can be made:

-- it is possible that some normal appearing breeding animals may be homozygous recessive as demonstrated by BERG and GOONEWARDENE (I976),

- the use of female carriers of the S.A.P. gene, detected as such because they have already produced an abnormal calf may well lead to an increased penetrance. That being the case, it may be wise to exert some selection against the tendency of certain carrier females to increase the penetrance of the S.A.P. gene when their offspring are homozygous recessive.

\section{The problem of eradication}

At Harrogate, a C.C.A. report (Anonymous, 1978) emphasized that the histopathological studies in Canada do not allow distinction to be made between the heterozygous carrier and the homozygous normal animals by a simple examination of the living animals.

But it does appear that the works of RUSSEL (I979) and RIEGER et al. (r979) could offer orientations for the search of some biochemical or morphological means of detection. 
The only method for the detection of normal appearing carriers (hetero or homozygous) remains a breeding test. Detection and removal of the carriers from the breeding population has so far been undertaken only in two countries and by different methods.

- In Canada, the C.C.A. set up an experimental herd of normal appearing carriers. As already stated, a part of this herd was used by RUSSEL (I976) to produce the abnormal embryos used in his studies. Sires to be tested were mated to these presumed heterozygous cows.

Apparently penetrance is very nearly complete (refer to the foregoing remarks concerning augmentation of penetrance in descendants of cows having aleardy produced a defective calf), so it would only be necessary to perform a few matings to identify the genotype of a bull with reasonable probability of not having made an error (QUANTZ, I976).

- In France, for pure bred bull testing, the frequency of the gene in the entire female propulation is used $(q=0.20)$ which is high enough but it doesn't have as high a penetrance as in the experimental herd in Canada. Also, the number of calves required for equal precision is much higher (about ten times). According to LEFORT et al. (I977), the probability of nondetection of a heterozygous carrier with I50 progeny is o.I6.

The advantage of the French method over the Canadian is the very low cost since the detection of abnormals is made in the ordinary routine of progeny performance testing. However, these two methods permit the testing and detection of only a small number of males each year, and in populations where artificial insemination is not used to any extent, at least in seed stock herds, they are not effective for eradication of the gene.

In fact, as concluded by LAUVERGNE and HOWELL (I977) in their report to F.I.A.E.R.B.C. it can be asked whether eradication is possible or even desirable.

To the first question, the reply is in the negative. Neither of the two methods examined above is capable of detecting all the carrier males in a breed. What's more, if the French method was rigidly applied it would become less and less effective because, as the gene frequency decreased in the female population, there would be required larger and larger numbers of progeny from a bull to eventually declare him a non carrier with the same high level of probability. In the event of there being a selective advantage for the heterozygote, eradication would be theoretically impossible (LEFORT and LAUVERG-NE, I974).

The second question can also be answered in the negative. For one thing the economic loss by S.A.P. is very low (0.5 p. Ioo of newborn calves compared to total losses from all causes currently about Io p. roo), and is probably less than the cost of an intensive eradication program. Secondly if the observations of BERG and GOONEWARDENE (I974) are accepted (that heterozygous females were more prolific than homozygous normal females), the losses caused by the abnormals would be less than the gains resulting from the heterosis phenomenon $(3.3 \mathrm{p}$. Ioo additional newborn calves at a gene frequency of $q=0.20$ ).

However, there are other reasons for undertaking an eradication program. Commercial considerations may dictate it, especially in North America where the competition among beef breeds is very keen. This partially explains the program undertaken by the C.C.A. to prove that nothing is neglected in breed improvement. Reasoning from the same position of commercial competition, authorities in the American Charolais Association (A.I.C.A.) have on the other hand chosen to systematically ignore the very existence of the anomaly, an attitude in line with the conclusions of a genetic study by LAUVERGNE (I979). 


\section{Conclusions}

Even if it is recommended to the various Charolais associations that the anomaly (S.A.P.) be ignored in their testing and selection programs, it would be desirable for them to routinely monitor cases of S.A.P. if only to be assured that it is truly S.A.P. and not an anomaly caused by a different gene or even a virus. In any case, the study of S.A.P. in all its manifestations at the histological and histochemical levels, is far from complete and must be pursued logically.

The fundamental neurobiologic studies of neuromuscular system in the S.A.P. calf could be developed with profit using the experience from the study of mutants in the Mouse (the already quoted $m d g$; RIEGER, I979), but also of variants in Man such as "Arthrogryposis multiplex congenita " studied by BANKER et al., r957. This type of studies could not only bring new views on the neuro-muscle contact and its stabilization but also new contributions to the knowledge of biochemical parameters in these pathological cases. It could even be possible in the future to detect normal overlap carriers by checking light abnomalities of some of these parameters in the living population of Charolais calves (RIEGER et al., r980).

It would be equally desirable to continue on-farm studies of the frequency of the syndrome in the pure breed and its crosses to confirm the values already reported in France and Canada.

\section{Chronological bibliography of S.A.P. papers $1976-1979$}

The numeration of the papers comes in the succession of the numeration of the I967-1975 article given by LAUVERGNE and FAUCON (1976). The omitted article by HARTLEY et al., 1974, has been put at the beginning, with a bis number.

I974

(37bis) HARTLEY W. J., WANNER R. A., I974. Bovine congenital arthrogryposis in New South Wales. Austr. Vet. J., 50, I85.

\section{$\mathbf{1 9 7 6}$}

(50) CoLE A. E., I976. Inherited arthrogryposis cleft palate syndrome in Charolais cattle in Australia. Proc. 53rd Annu. Conf. Austr. Vet. Assoc., Ir6-rr8.

(5I) GoOnewardene L. A., Berg R. T., 1976. Arthrogryposis in Charolais cattle: a study of gene penetrance. Ann. Génét. Sél. anim., 8, 493-499.

(52) LaUvergne J. J., I976. Compte-rendu d'une mission d'information sur le Syndrome d'Arthrogrypose et de Palatoschisis en race Charolaise au Canada. I.N.R.A., Dépt. de G énétique animale C.N.R.Z., Jouy-en-Josas, France, I8 p.

(53) Lauvergne J. J., Faucon A., 1976. Le syndrome d'Arthrogrypose et de Palatoschisis (SAP) en race bovine Charolaise. Bibliographie annotée 19671975. Ann. Génét. Sél. Anim., 8, 51-70.

(54) QuAnTz L., I976. C.C.A. Newsletter. Genetic testing. Can. Charolais Banner, June 60. 
(55) Russei. R. G., I976. a) A proposal for establishing a herd of cows at Goodale Farm to study inherited muscular dystrophy. Without ref., 2 p.

(56) RUSSELL R. G., r976. b) A study of Arthrogryposis in Charolais calves using a test herd at the University of Saskatchewan. Dept. Vet. Path., Western College Vet. Medicine, Saskatoon, 2 p.

\section{I977}

(57) Anonymous, I977. Report to the technical committee on progress in the study of arthrogryposis (Canada). Congr. F.I.A.E.R.B.C., Monterrey Mexico, 6 p.

(58) LAUVERGNe J. J., Howeli W. E., I977. Le syndrome d'arthrogrypose et de palatoschisis en race Charolaise : estimation de la fréquence, détection des porteurs et éradication. Rapport au Comité technique de la F.I.A.E.R.B.C., Nevers, 7 p., ronéoté.

(59) LeForT G., LAUUVERGne J. J., Fabrègue P., I977. Fréquence et pénétrance $\mathrm{du}$ gène responsable du Syndrome d'Arthrogrypose et de Palatoschisis dans le bétail Charolais en France. Ann. Génét. Sél. anim., 9, 283-300.

(6o) Logue D. N., Breeze R. G., Harvey M. J. A., r977. Arthrogryposispalatoschisis and a I/29 translocation in a Charolais herd. Vet. Rec., 100, 500-5I0.

(6I) Nieisein N. O., Russeil, R. G., Smith D. L. T., r977. Report on congenital and inherited disease of cattle. Canada Dept. of Supply and Service, Contract File $025 \mathrm{~W}$, orTo2-5-0092, I2 p.

(62) Russeil R. G., 1977. Studies of the Syndrome of Arthrogryposis and Palatoschisis (S.A.P.). Report to the F.I.A.E.R.B.C., Monterrey, Mexico, I2-I4 Oct. I977, I7 p.

\section{I978}

(63) Anonymous, 1978. Arthrogryposis. In "Delegates meeting "XVth World Charolais Convention, Harrogate, Yorksh., I7-9-78, 4.

(64) Hanset R., Leroy P., Michaux O., r978. Le Syndrome arthrogrypose et Palatoschisis (S.A.P.) dans un troupeau de croisés Charolais. Ann. Méd. Vét., $122,59 \mathrm{r}-596$.

(65) HoweLL, W. E., LAUVERGNe J. J., I978. S.A.P. frequency in Saskatchewan Charolais cattle. Ann. Génét. Sél. anim., 10, I7I-I79.

(66) JACKSON A. E., I978. Congenital arthrogryposis in Charolais calves. Vet. Rec., 102, I49-I50.

(67) LAUVERGNE J. J., I979. Le Charolais américain et ses problèmes de génétique mendélienne : compte-rendu d'une visite à l'A.I.C.A., Houston, les 7 et 8 mars I979. Dépt. Génétique Animale, C.N.R.Z., Jouy-en-Josas, France, 6 p.

(68) Lauvergne J. J., Howeli W. E., Rieger F., Faucon A., I979. A review of literature on the Syndrome of Arthrogryposis and Palatoschisis (S.A.P.) in Charolais cattle: 1976-1979. Ann. Génét. Sél. anim., 11, 27r-280. 
(69) Riegeir F., Pinçon-Raymond M., Dreyfus P., Fardeau M., i979. Abnormal motor innervation and defect in the focalisation of the multiple forms of acetylcholinesterase in S.A.P. calf muscle. Ann. Génét. Sél. anim., 11 (in press).

(70) Russeli R. G., I 979. Studies of neuromuscular development in inherited syndrore of Arthrogryposis and Palatoschisis in Charolais cattle. Ph. D. Thesis, Dept. Vet. Path. Western College of Vet. Medicine Univ. of Saskatchewan, Saskatoon Sask. Canada, 345 p.

$$
\text { I980 }
$$

Rieger F., Pinçon-Raymond M., Dreyfus P., Koenig J,, Fardeau M., I980. Nerve and muscle defects in S.A.P. calves. In vivo and in vitro studies (in preparation).

\section{Author index for S.A.P. papers 1976-1979}

AnONYMOUS, I977, 57.

ANONYMOUS, I978, 63.

BERG R. T., 5I.

BREEZE R. G., 60.

COLE A. E., 50.

DREYFUS P., 69.

FABRECUE P., 59.

FARDEAU M., 69.

FAUCON A., 53, 68.

HANSET R., 64.

HARTLEY W. J., 37 bis.

HARVEY J. A., 60.

GOONEWARDENE L. A., 5I.

HOWELL, W. E., 58, 68.
JACKSON A. E., 66.

LAUVERGNE J. J., 52, 53, 58, 59, 67, 68 .

LEFORT G., 59.

LEROY P., 64.

LOGUE D. N., 60.

Michaux C., 64.

NIEL,SEN N. O., 6 I.

Pinçon-RAYMond M., 69.

QUANTZ L., 54.

RIECER F., 68, 69.

Russei, R. G., 55, 6I, 62, 70.

SMITH D. L. T., 6I.

WANNER R. A., 37 bis.

\section{Subject index for S.A.P. papers 1976-1979}

Australia 37 bis, 50 .

Belgium (new cases): 64 .

Canada (report on): 52, 54, 55, 6I, 63 .

Eradication: 54 .

Estimation of gene frequency and

penetrances: $5 \mathrm{I}, 58,59,65$.
Expression of the gene: $57,62,69,70$. Great Britain (new cases): 60, 66. Review: 53, 68.

U.S.A. (report on): 67 .

\section{In Memoriam}

Last November 1979, G. LEFORT Professor of Mathematics at the Institut National Agronomique Paris-Grignon (France) has suddenly disappeared.

His contribution to the study of S.A.P. in Charolais is noticeable. First he helped us in 
establishing the equation for measuring gene frequency and penetrances in the French Charolais population. He then contributed to estimate these parameters in the French population as well as in the Saskatchewan one.

He gave also the basic principle for the law of eradication of gene in the case we are interested in.

Without him the difficult statistical situations we faced in the study of S.A.P. as well in France as in Canada could certainly not have been so quickly solved.

\title{
Résumé
}

\author{
Synthèse des travaux relatits au syndrome d'arthrogrypose \\ et de palatoschisis (S.A.P.) chez les bovins Charolais I976-I979
}

Depuis 1976 , une vingtaine d'articles se sont ajoutés aux 49 déjà cotés dans une bibliographie signalétique publiée en 1976 .

Des progrès importants dans la description du syndrome sont notés : 1'âge d'apparition chez l'embryon est déterminé (autour de 3 mois et demi); l'anomalie de départ frappe le système nerveux au niveau de la plaque motrice. Il s'ensuit une désorganisation du muscle. L'anomalie est fort semblable à une affection héréditaire de la Souris, la muscular dysgenesis (mdg).

La fréquence de l'anomalie en race Charolaise pure, aussi bien en France qu'au Canada, s'établit à $0,5 \mathrm{p}$. I 00 des veaux naissant. La fréquence du gène serait $q=0,20$ et les pénétrances chez les homozygotes respectivement o, I 5 chez les mâles et 0,09 chez les femelles.

On a expliqué que, dans certains cas, la pénétrance peut paraître totale à cause de différences dans les probabilités d'enregistrement des fratries selon le nombre d'anormaux apparus, et que, dans le cas de croisements à partir d'animaux porteurs détectés d'après leur descendance, une certaine sélection a pu jouer pour augmenter cette pénétrance.

Deux méthodes de détection des mâles porteurs du gène ont été expérimentées : au Canada, à l'aide d'un troupeau expérimental de femelles porteuses, en France, dans le cadre du testage viande en race pure. Dans les deux cas, un nombre infime de taureaux a pu être testé par rapport aux besoins de la race. L'éradication de la tare, matériellement impossible, semble également théoriquement inutile, du moins économiquement parlant car les femelles hétérozygotes pourraient être plus prolifiques, ce qui compenserait, et au-delà, les faibles pertes dues à la présence du gène dans la population. Cependant, les associations peuvent tenir compte d'autres considérations que des considérations purement économiques et génétiques pour orienter leur action, en particulier des considérations commerciales.

Pour conclure, il est souhaitable que l'on continue de repérer les veaux S.A.P. d'une manière routinière pour éviter de confondre avec d'autres possibles anomalies. Les études sur les manifestations à tous les niveaux et sur l'étiologie pure de l'anomalie sont également préconisées. On aimerait également avoir des précisions supplémentaires sur l'avantage de prolificité des femelles hétérozygotes.

\section{General bibliography}

Anonymous, 1977. Report to the technical committee on progress in the study of arthrogryposis. Cong. F.I.A.E.R.B.C., Monterrey, Mexico, 6 p.

Anonymous, I978. Arthrogryposis. In Delegates Meeting, XVth World Charolais Convention, Harrogate, Yorksh., I 7-9-78, p. 4.

BERG R. T., GOONEWARDENE I. A., I974. The genetics of arthrogryposis in Charolais cattle. Ist World Congr. Genet. Appl. Anim. Breed., 1, 635-642.

COLE, A. E., r976. Inherited arthrogryposis cleft palate syndrome in Chavolais cattle in Australie. Proc. 53rd Annu. Conf. Aust. Vet. Assoc. I $16-$ I 18.

Giroud A., I975. Les arthromyodysplasies dans l'espèce bovine. Rev. Méd. Vét., 151, 44I-446.

GOONEWARDENE L. A., BERG R. T., I976. Arthrogryposis in Charolais cattle: a study of gene penetrance. Ann. Génét. Sél. Anim., 8, 493-499. 
Hanset R., LeRoy P., Michaux C., 1978. Le Syndrome Arthrogrypose et Palatoschisis (S.A.P.) dans un troupeau de croisés Charolais. Ann. Méd. Vét., 122, 591-596.

HARTLEY W. J., WANNER R. A., 1974. Bovine congenital arthrogryposis in New South Wales. Austr. Vet. J., 50, 185 .

Howel. W. E., LAUVERGNE J. J., 1978. S.A.P. frequency in Saskatchewan Charolais cattle. Ann. Génét. Sól Anim., 10, i 7I-I 79 .

JACKSON A. E., 1978. Congenital arthrogryposis in Charolais calves. Vet. Rec., 102, 149-150.

LAUVERGNE J. J., I975. État actuel des connaissances sur le syndrome d'arthrogrypose et de palatoschisis (S.A.P.) dans le bétail Charolais de France. Ann. Génét. Sél. Anim., 7, 321-330.

LAUVERGNE J. J., 1976. Compte rendu d'une mission d'information sur le syndrome d'arthrogrypose et de palatoschisis en race charolaise au Canada. I.N.R.A., Dépt. de Génétique animale, C.N.R.Z., Jouy-en-Josas, France, I 8 p.

LAUVERGNE J. J., I979. Le Charolais américain et ses problèmes de génétique mendélienne : compte rendu d'une visite à l'A.I.C.A., Houston, les 8 et 9 mars 1979. I.N.R.A, Département de Génétique Animale. C.N.R.Z., Jouy-en-Josas, France, 6 p.

LAUVERGNE J. J., BLIN P. C., I967. Fissure palatine héréditaire associée à l'ankylose des membres dans la race Charolaise. Ann. Zootech., 16, 291-30o.

LAUVERGNE J. J., FAUCON A., I976. Le syndrome d'arthrogrypose et de palatoschisis (S.A.P.) en race bovine Charolaise : bibliographie annotée 1967-1975. Ann. Génét. Sél. Anim., 8, 51-70.

LAUVERGNe J. J., Howel, W. E., 1977. Le Syndrome d'Arthrogrypose et de Palatoschisis en race Charolaise : estimation de la fréquence, détection des porteurs et éradication. Rapport au Comité Technique de la F.I.A.E.R.B.C., Nevers, 7 p.

LEFORT G., LAUVERGNE J. J., I974. L'éradication des gènes récessifs à effets visibles dans des populations bovines où les taureaux sont mis à l'épreuve sur leur descendance. C. R. Acad. Sc. Paris, 279, série D, $138 \mathrm{I}-\mathrm{I} 384$.

LEFORT G., LAUVERGNE J. J., FABRÈGUE P., 1977. Fréquence et pénétrance du gène responsable du Syndrome d'Arthogrypose et de Palatoschisis dans le bétail Chavolais en France. Ann. Génét. Sél. Anim., 9, 283-300.

LOGUE D. N., BREEZE R. G., HARVEY J. A., 1977. Arthrogryposis-palatoschisis and a I/29 translocation in a Charolais herd. Vet. Rec., 100, 509.

Nawrot P. S., 1973. Arthrogryposis, a congenital defect in newborn calves. M. S. Thesis, Dept. Anim. Sc. Univ. Saskatchewan, Saskatoon, $13^{8} \mathrm{p}$.

NAwROT P., 1976. A biochemical study of hereditary muscular dysgenesis (mdg) mutant in the Mouse. Ph. D. thesis Dept. anim. Sci. Univ. Saskatchwan, Saskatoon.

NAWROT P., HOWELL, W. E., WENGER B. S., 1979. Biochemical and electrophoretic studies of cholinesterases in the muscular dysgenesis (mdg) mutant mouse. Teratology, 20, 7-16.

NIFLSEN N. O., RUSSEL R. G., SMITH D. L. T., 1977. Report on congenital and inherited disease of cattle. Canada Dept of Supply and Services Contract. File 025 W oITo2-5-0092, I 2 p.

Quantz L., I976. C.C.A. Newsletter: Genetic testing. Can. Charolais Banner, June, 6o.

Rieger F., Pinçon-Raymond M., Dreyfus P., Fardeau M., 1979. Abnormal motor innervation and defect in the focalisation of the multiple forms of acetylcholinesterase in S.A.P. calf muscle. Ann. Génét. Sél. anim., 11 (in press).

RIEger F., Pinçon-Raymond M., Dreyfus P., Koenig J. Fardeau M., 1980. Nevve and muscle defects in S.A.P. calves; in vivo and in vitro study (in preparation).

RUSSEL R. G., 1976a. A proposal for establishing a herd of cows at Goodale Farm to study inherited muscle dystrophy. Sans réf., 2 p. (University of Saskatchewan, Saskatoon).

RUSSEr R. G., r976b. A study of Arthrogryposis in Charolais calves using a test herd at the University of Saskatchewan. Dept. Vet. Path., Western College Vet. Medicine, Saskatoon, 2 p.

RUSSEIL R. G., I977. Studies of the syndrome of arthrogryposis and palatoschisis (S.A.P.). Report to the F.I.A.E.R.B.C. in Monterrey, Mexico, October I2-14 1977, I 7 P.

RUSSELL R. G., 1979. Studies of neuromuscular development in inherited syndrome of arthrogryposis and palatoschisis in Charolais cattle. $\mathrm{Ph}$. D, Thesis, Vet. Path. Western College of Veterinary Medicine University of Saskatoon, Sask., Canada. 